\title{
Comparative Assessment of Energy Values of Briquettes from Some Agricultural By-Products with Different Binders
}

\author{
Idah, P. A ${ }^{1}$, Mopah, E. J ${ }^{2}$ \\ ${ }^{1,2}$ Department of Agricultural and Bioresources Engineering, Federal University of Technology, P.M. B. 65 , \\ Minna, Niger State, Nigeria.
}

\begin{abstract}
The effect on environment by agricultural and other industrial wastes is on the increase and is causing a lot of problem. Adequate means of disposing these wastes are lacking, hence, converting them to other useful products such as briquettes for domestic fuel is desirable. In this work, the energy values of briquettes made from some of these agricultural by-products using two binders were assessed. Wastes from rice husk, maize cob, groundnut shell and sugarcane baggasse were turned to briquettes using two different types of agricultural byproduct binders (banana peel and cassava peel gel). The briquettes were subjected to energy evaluation test using the Fulton XRY-1B Oxygen Bomb Calorimeter. The mean bulk densities of the briquettes produced from rice husk, maize cob, groundnut shell and sugar cane baggasse were $0.75 \mathrm{~g} / \mathrm{cm}^{3}, 0.69 \mathrm{~g} / \mathrm{cm}^{3}, 0.81 \mathrm{~g} / \mathrm{cm}^{3}$ and $0.65 \mathrm{~g} / \mathrm{cm}^{3}$, respectively. The results obtained showed that the average energy values of the briquettes produced using cassava peel as binder from rice husk, maize cob, groundnut shell and sugarcane baggasse were $26.612 \mathrm{MJ} / \mathrm{Kg}, 28.255 \mathrm{MJ} / \mathrm{Kg}, 33.703 \mathrm{MJ} / \mathrm{Kg}$ and $32.762 \mathrm{MJ} / \mathrm{Kg}$, respectively. The corresponding average values for those produced using banana peel as binders were $29.980 \mathrm{MJ} / \mathrm{g}, 28.981 \mathrm{MJ} / \mathrm{g}, 32.432 \mathrm{MJ} / \mathrm{g}, 31.508 \mathrm{MJ} / \mathrm{g}$ for rice husk, maize cob, groundnut shell and sugarcane baggasse, respectively. The results indicate that briquettes produced from groundnut shell using cassava peel gave the highest energy value of $33.70 \mathrm{MJ} / \mathrm{kg}$ while those obtained from rice husk using cassava peel gave the lowest calorific value of $26.61 \mathrm{MJ} / \mathrm{kg}$ and these were significantly different $(\mathrm{p} \leq 0.05)$. The briquette from groundnut shell is therefore more suitable for starting and maintaining fire for cooking and other domestic heating. The briquettes from these by-products in terms of energy values are ranked as follows: groundnut shell > sugar cane baggasse > maize cob > rice husk. The effective utilization of these agricultural by-products as high grade solid fuel can reduce environmental pollution resulting from the wastes and also help in minimizing the energy crisis resulting from non- renewable energy sources like petroleum products as domestic fuel.
\end{abstract}

Keywords: agricultural by-products, binding materials, briquettes, energy values

\section{INTRODUCTION}

Agricultural waste (by-products) management during processing is one of the most serious rural-urban environmental problems in developing countries. Several tonnes of agricultural by-products such as groundnut shell, sugar cane baggasse, rice husk, maize stalk, palm kernel shell and others are generated in Nigeria annually which constitute environmental hazard and when burnt off result in air pollution. The average tonnage of excess baggasse produced per year is over 24,000 tons [1]. Some of these agricultural by-products have values and could be utilized based on the popular slogan of four "R's" (Reduce, Reuse, Recover and Recycle). By-products from Agricultural processing can be transformed into more useful products like briquettes, which provide important alternative sources of energy for domestic use (cooking fuel).

It is noted that wood in form of fuel wood and charcoal constituted the major source of renewable energy accounting for about $51 \%$ of the total energy consumption in Nigeria. Others include natural gas (5.2\%), hydro electricity (3.1\%) and petroleum products $(41.3 \%)$ [2]. However, the decreasing availability of wood, coupled with the ever rising cost of kerosene and cooking gas in Nigeria is forcing energy users to consider alternative sources of energy for domestic uses. One energy source that could find ready utilization is the fuel briquette.

Uses of biomass fuel such as composite sawdust briquette have been found to be a good source of renewable energy for domestic cooking [3]. In seventeenth century, the rural poor often burn dried cow dung because of the acute shortage of wood fuel and wide spread deforestation. The conversion of Agricultural byproducts, wood waste and coal dust to high energy value briquettes for cooking and drying have been investigated and found to be feasible [4].

However, the performance of any solid biomass fuel such as sawdust briquette is evaluated effectively when it is combusted $[4 ; 5]$. The energy content of the briquettes vary depending on the materials used. It is thus important to assess the energy values of some of the briquettes made from some of these readily available agricultural by-products with a view to ascertaining the economic viability of embarking on mass production of 
such briquettes. It is also important to evaluate the effect of binders on such energy values of briquettes.

Results from recent studies have shown that agricultural by-products mixed with biomass materials especially palm kernel shells of appropriate grain size in certain proportion have improved calorific value [6]. The addition of palm kernel shell to ordinary saw dust improves the calorific value of the formed briquette from $18 \mathrm{MJ} / \mathrm{kg}$ to about $23 \mathrm{MJ} / \mathrm{kg}$

$[4,7,5]$. It could be seen from available data that the utilization of agricultural by-products apart from sawdust for briquetting in Nigeria is at very low ebb compared to other developing countries. One major reason could be attributed to lack of adequate information on the viability of these wastes for briquetting and the energy values contained there-off.

In this study, the energy values of briquettes produced from four agricultural by-products using two different agricultural-products binders were quantified to ascertain which of these by-products is more viable as far as renewable energy production for domestic fuel is concerned.

\subsection{Raw Materials Preparation}

\section{MATERIALS AND METHODS}

The following combustible agricultural by-products from different waste dump sites were considered for this project: Rice husk, Groundnut shell, Sugarcane baggasse and Maize cob.

Rice husk was collected from the dump site and gel made from cassava peel was mashed and weighed (166.67g) using a Mettler PM 200 electrical weighing balance( 0.01 sensitivity) and placed in a cylindrical mould of known volume. The physical properties (volume and density) of the material were determined. This mould was fed into hydraulic briquetting machine which was operated at a maximum pressure of $60 \mathrm{kN} / \mathrm{m}^{2}$ to enhance perfect compaction. The mould was placed over an appropriate opening and the formed cylindrical briquettes were extracted by gradual application of pressure at the hydraulic jack. The same process was repeated with rice husk mashed with banana peel as binder. The above processes were repeated for maize cob, sugar cane baggasse and groundnut shell using the same cassava peel gel and banana peel as binders. The briquettes produced were allowed to dry in the sun for seven days and then assessed for their energy.

A Fulton XRY-1B Oxygen Bomb Calorimeter interfaced with a microcomputer (Plate 9) was used to assess the heat values of the produced briquettes. One (1) gramme of the briquettes was measured and the screw mould bracket was used to re-mould the briquette to the appropriate calorimeter bucket size. Ten (10) $\mathrm{ml}$ distilled water was poured into the bomb and the industrial oxygen cylinder was connected to the bomb and the valves were opened and bomb was filled slowly at pressure range of $2.5-3.0 \mathrm{Mpa}$ for a minute. The bomb was placed inside a canister bracket containing the distilled water and the bomb lid was covered. The switch was turned on and the microcomputer was set for the determinations which automatically calibrate and measure the energy values and display the values on the screen for recording after feeding the necessary data on the briquettes. The residues (ash content) after burning were removed and weighed. The data obtained were subjected to statistical analysis using SPSS 7.0, to ascertain if there were significant differences between the means of the values obtained.

\subsection{Physical Parameters of Briquettes}

\section{RESULTS AND DISCUSSION}

The physical properties of the materials before and after briquetting were determined and the results are presented in Table 1. The results showed that the mean values the bulk densities of the briquettes produced from rice husk, maize cob, groundnut shell and sugar cane baggasse were $0.75 \mathrm{~g} / \mathrm{cm}^{3}, 0.69 \mathrm{~g} / \mathrm{cm}^{3}, 0.81 \mathrm{~g} / \mathrm{cm}^{3}$ and $0.65 \mathrm{~g} / \mathrm{cm}^{3}$, respectively. The average values of the desensities obtained fell within the values obtained in earlier studies, especially for the rice husk [8] which gave the value of density of extruded rice husk char briquette as $0.81 \mathrm{~g} / \mathrm{cm}^{3}$.

One very important parameter in briquette production is the density. The density of biowaste briquettes depends on the density of the original biowaste, the pressure, temperature and time of desensification. The higher the density, the higher is the energy/volume ratio. 
Comparative Assessment of Energy Values of Briquettes from Some...

\begin{tabular}{|c|c|c|c|c|c|c|}
\hline Sample & Materials & $\begin{array}{l}\text { Volume before } \\
\text { briquetting } \\
\left(\mathrm{cm}^{3}\right)\end{array}$ & $\begin{array}{c}\text { Bulk } \\
\text { Density } \\
\text { before } \\
\text { briquetting } \\
\left\{\mathrm{g} / \mathrm{cm}^{3}\right\}\end{array}$ & $\begin{array}{c}\text { Volume after } \\
\text { briquetting } \\
\left(\mathrm{cm}^{3}\right)\end{array}$ & $\begin{array}{c}\text { Bulk Density } \\
\text { after } \\
\text { briquetting } \\
\left\{\mathrm{g} / \mathrm{cm}^{3}\right\}\end{array}$ & Mean \\
\hline A1. & $\begin{array}{c}\text { Rice husk \& } \\
\text { cassava peel } \\
\text { gel }\end{array}$ & 100.53 & 1.67 & 67.86 & 0.72 & \\
\hline A 2. & $\begin{array}{l}\text { Rice } \\
\text { husk/banana } \\
\text { peel }\end{array}$ & 100.53 & 1.67 & 72.89 & 0.78 & 0.75 \\
\hline B1. & $\begin{array}{c}\text { Maize } \\
\text { cob/cassava } \\
\text { peel gel }\end{array}$ & 100.53 & 1.67 & 60.32 & 0.68 & \\
\hline B2. & $\begin{array}{c}\text { Maize } \\
\text { cob/banana } \\
\text { peel }\end{array}$ & 100.53 & 1.67 & 65.35 & 0.69 & 0.69 \\
\hline C1. & $\begin{array}{l}\text { Groundnut } \\
\text { shell/cassava } \\
\text { peel gel }\end{array}$ & 100.53 & 1.67 & 76.66 & 0.81 & \\
\hline $\mathrm{C} 2$. & $\begin{array}{l}\text { Groundnut } \\
\text { shell/banana } \\
\text { peel }\end{array}$ & 100.53 & 1.67 & 80.42 & 0.80 & 0.81 \\
\hline D1. & $\begin{array}{c}\text { Sugarcane } \\
\text { baggasse/cassa } \\
\text { va peel gel }\end{array}$ & 100.53 & 1.67 & 56.55 & 0.66 & \\
\hline D2. & $\begin{array}{c}\text { Sugarcane } \\
\text { baggasse/bana } \\
\text { na peel }\end{array}$ & 100.53 & 1.67 & 62.83 & 0.63 & 0.65 \\
\hline
\end{tabular}

\subsection{Calorific Values of Briquettes}

The measured energy values of the produced briquettes from the selected agricultural by-products are shown in Table 2. The results showed that irrespective the binders used, the average calorific values of the briquettes from rice husk, maize cob, groundnut shells and sugar cane baggasse were $28.30 \mathrm{MJ} / \mathrm{kg}, 28.62 \mathrm{MJ} / \mathrm{kg}$, $33.07 \mathrm{MJ} / \mathrm{kg}$ and $32.30 \mathrm{MJ} / \mathrm{kg}$, respectively. The corresponding ash contents measured were $0.17 \mathrm{~g} / 100 \mathrm{~g}$, $0.05 \mathrm{~g} / 100 \mathrm{~g}, 0.06 \mathrm{~g} / 100 \mathrm{~g}$ and $0.03 \mathrm{~g} / 100 \mathrm{~g}$ for rice husk, maize cob, groundnut shells and sugar cane baggasse, respectively.

Table 2: Mean Calorific Values and Ash contents of Briquettes

\begin{tabular}{|c|c|c|c|c|c|}
\hline Sample & Briquette & $\begin{array}{c}\text { Heat value } \\
\{\mathrm{MJ} / \mathrm{kg}\}\end{array}$ & Mean & $\begin{array}{c}\text { Ash content } \\
\{\mathrm{g}\}\end{array}$ & Mean \\
\hline A1. & $\begin{array}{c}\text { Rice Husk \& } \\
\text { cassava peel gel }\end{array}$ & 26.612 & & 0.18 & \\
\hline A2. & $\begin{array}{c}\text { Rice Husk \& } \\
\text { banana peel }\end{array}$ & 29.980 & $28.30 \mathrm{a}$ & 0.16 & 0.17 \\
\hline B1. & $\begin{array}{c}\text { Maize cob \& } \\
\text { cassava peel gel }\end{array}$ & 28.255 & & 0.06 & \\
\hline B2. & $\begin{array}{c}\text { Maize cob \& } \\
\text { banana peel }\end{array}$ & 28.981 & $28.62 \mathrm{a}$ & & 0.05 \\
\hline C1. & $\begin{array}{l}\text { Ground nut shell \& } \\
\text { cassava peel gel }\end{array}$ & 33.703 & & 0.04 & \\
\hline $\mathrm{C} 2$. & $\begin{array}{c}\text { Ground nut shell \& } \\
\text { banana peel }\end{array}$ & 32.432 & $33.07 \mathrm{~b}$ & 0.08 & 0.06 \\
\hline D1. & $\begin{array}{c}\text { Sugar cane } \\
\text { baggasse \& } \\
\text { cassava peel }\end{array}$ & 32.762 & & 0.02 & \\
\hline D2. & Sugar cane & & $32.14 \mathrm{~b}$ & & 0.03 \\
\hline
\end{tabular}


Comparative Assessment of Energy Values of Briquettes from Some...

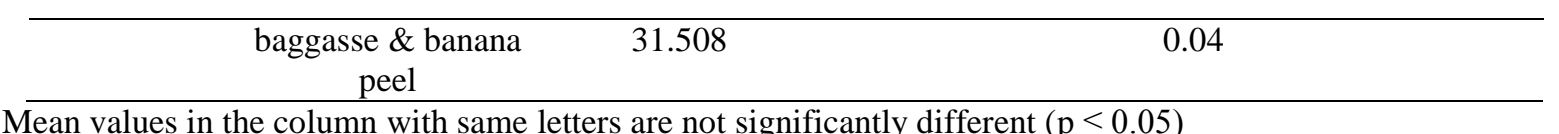

IV. DISCUSSION

Energy problems are well known. Natural resources and primary energy sources are becoming scarce. Supply of new and alternative energy sources has become a necessity in order to provide better outcome from energy cost and efficiency. In this regard, briquetting of agricultural wastes /crop residues provides an excellent energy source and an environmental friendly combustible fuel. This actually prompted this present studies which is aimed at comparing the calorific values of briquettes produced from some available agricultural residues using also biomaterial by-products as binders.

The results in Table 1 show that the volume and bulk density of agricultural by-products were reduced by about thirty percent $(30 \%)$ after conversion to a more useful product like briquette. This in essence helps in reducing the cost and labour involved in handling the raw bulk materials which usually constitute hazard in the dump ground. The reduction in the volume also saves space for storage of these products.

The moisture contents of the biomass used for the production of the briquettes were in the range of $12-$ $16 \%$ (wet basis) and this actually facilitated the compaction of the materials. However, the average moisture content of the briquettes produced was $8 \%$ (wet basis). This average moisture content of the briquettes though slightly higher than the $5 \%$ obtained for sawdust briquettes [2] however, falls within the range $(7.7-15.1 \%)$ reported by [9] for sawdust and wheat straw briquettes. The ranges recommended for good storability and combustibility of briquettes are $12-20 \%$ (wet basis). It is noted that moisture content in excess of $20 \%$ would result in considerable loss of energy during combustion.

The results showed that the average heat value or calorific value of briquettes obtained from agricultural wastes used in this study ranged from $28.30 \mathrm{MJ} / \mathrm{kg}$ to $33.07 \mathrm{MJ} / \mathrm{kg}$ using the oxygen bomb calorimeter irrespective of binders used. The average values compared favourably with values given in literature although with some slight differences. For instance, much research work has been carried out on sawdust briquettes and some agricultural by-products briquettes in respect to their energy values. These values ranges between $18 \mathrm{MJ} / \mathrm{kg}-23 \mathrm{MJ} / \mathrm{kg}[4 ; 7 ; 5]$ for briquettes produced from sawdust mixed with palm kernel shells and also those given by [10] for some other biomaterials. It has been noted that the calorific content of materials vary depending on the calorimetry method [10].

It can be seen from the results (Table 2) that briquettes produced from groundnut shells using cassava peel as binder gave the highest energy value of $33.70 \mathrm{MJ} / \mathrm{kg}$, while the briquettes obtained from the rice husk using cassava peel produced the least energy value of $26.61 \mathrm{MJ} / \mathrm{kg}$ and these values are significantly different ( $\mathrm{p}$ $\leq 0.05$ ). It can be seen that the briquettes from the groundnut shells also have the highest values of bulk density and the energy values of the briquette are influenced by the density. The higher the density the higher the energy values [8]. It has been noted [11] that groundnut shell is an excellent material for briquetting because of its low ash content and moisture content of less than $10 \%$ (wet basis).

Similarly, rice husk could make excellent fuel but its calorific value is less than wood and other agroresidue [11]. The other agro-residues, maize cob and sugar cane baggasse, used here gave calorific values which fell in between these two extremes.

On the bases of the binders used, there are no clear cut pattern regarding the calorific values of the briquettes produced using these two types of binders. Whereas the calorific values of the briquettes produced from rice husk and maize cob using banana peel are higher than those of briquettes produced using cassava peel as binders, the reverse is the case with those briquettes produced from groundnut shells and sugar cane baggasse. However, it is noted that variation in energy values could be attributed to the choice of the binders used for briquetting. For instance, cement, clay, animal dung, bitumen, gum Arabic have often been used in the past as binders for briquetting. These binders are not economically viable for briquetting as there are other competing needs in their usage compared to banana and cassava peels binders used in this work which essentially have no other valuable uses. It is also revealed that the combustibility and energy values of briquettes from these binders especially those from cement, clay and adhesive minerals are low and that combustible binders are preferred [12].

Currently, the production and utilization of briquettes especially from agricultural by-products which abound in large quantities in Nigeria is not well established. Part of the reasons for low utilization of these biomass materials for briquetting could be attributed to lack of adequate data/information on their potentials. Some samples of the briquettes produced are as shown in Plates $1-8$.

\section{CONCLUSION}

The large volume of agricultural by-products being generated in Nigeria and which constitute environmental hazard calls for effective utilization of these high grade biomass materials for solid fuel called 
briquettes. In this study, a comparative assessment of the calorific values of briquettes produced from four of these biomass materials was carried out. It is concluded that briquettes made from groundnut shells using cassava peel as binder gave the highest energy value during combustion while the least energy was produced by briquettes produced from rice husk using cassava peel as binder.

In view of this, the production of agricultural by-products briquettes can greatly provide alternative energy sources for domestic cooking in Nigeria and also serve as a measure in curbing the environmental hazard posed by poor methods of agricultural waste disposal in addition to reducing the popular use of charcoal which has an adverse effect on our environment (deforestation).

\section{REFERENCES}

[1]. J.R. Keya, T.S. Kumar and P. Vasudevan, Pattern of Non-Commercial energy consumption in India domestic sector - A Case Study Published by IIED London, 2000.

[2]. O. M. Aina, A. C. Adetogun, and K.A. Iyola, Heat energy from value-added sawdust briquettes of Abizia zygia. Ethopian Journal of Environmental Studies and Management, 2 (1), 2009, 42- 49

[3]. A. O. Kuti, Performance of composite sawdust briquette fuel in biomass stove under simulated condition. Au Journal of Technology, 12 (4), 2009, -288

[4]. C.O. Adegoke, A Preliminary investigation of sawdust as high grade solid fuel, Nigeria Journal of Renewal Energy (NJRE), 7 (1\&2), 1999, 102 - 107.

[5]. C.O. Adegoke and T.I. Mohammed, Investigation of briquette as high grade fuel, the West India Journal of Engineering, 2002. Faculty of Engineering, University of West India

[6]. K.K. Jacob, N.M. Simon, M. Jonathan, N.S. Canon and E. Wanjongo, Recycling waste into fuel briquettes, www.formatkenya.org/ormbook/chapters/chapter15 htm, 2005.

[7]. C.O. Adegoke, Waste to wealth: sawdust briquette as a case study, Paper presented at the Mechanical Division of NSE conference, held at Lafia Hotel Ibadan 20 - 21 April, 2001.

[8]. D. Ayhan and S. Ayse, Evaluation of biomass residue1. Briquetting waste paper and wheat straw mixtures. Fuel Processing Technology, 55,1998, 175-183.

[9]. L. Wamukonya, and B. Jenkins, Durability and relaxation of sawdust and wheat-staw briquettes as possible fuels for Kenya. Biomass and Bioenergy 8(3), 1995, 175 -179.

[10]. M, Owen, E. Seth and W. Nick, Biomass Briquettes: Turning Waste into Energy. Biomass, 2010.

[11]. FAO, Biomass Briquetting: Technology and Practices. Regional Wood Energy Development Programme in Asia GCP/RAS/154/NET. Edited by P.D. Grover and S.K Mishra, 1996.

[12]. A.O Olorunnisola, The development and performance evaluation of a briquette burning stove: Nigeria Journal of Renewable Energy, 7 (1 and 2), 1999, 91 - 95.

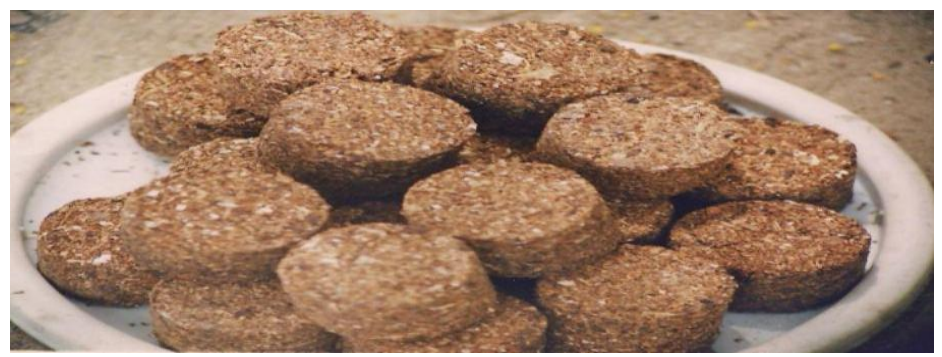

Plate1: Briquettes produced from rice husk and cassava peel gel binder

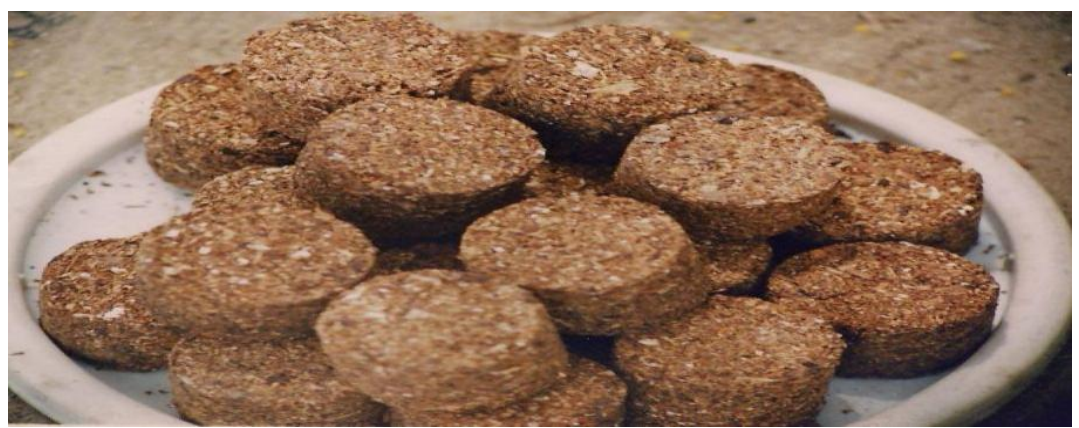

Plate 2: Briquettes produced from rice husk and banana peel binder 


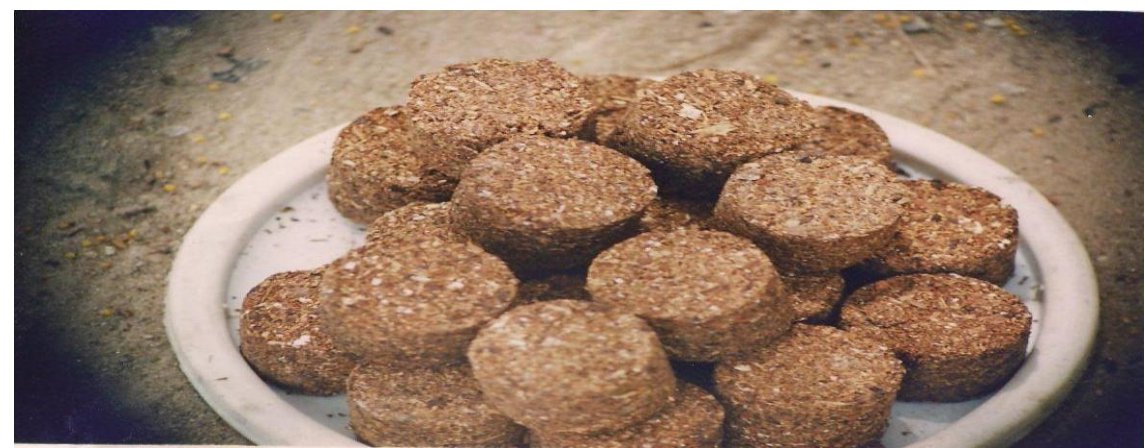

Plate 3: Briquettes produced from maize cob and cassava peel gel binder

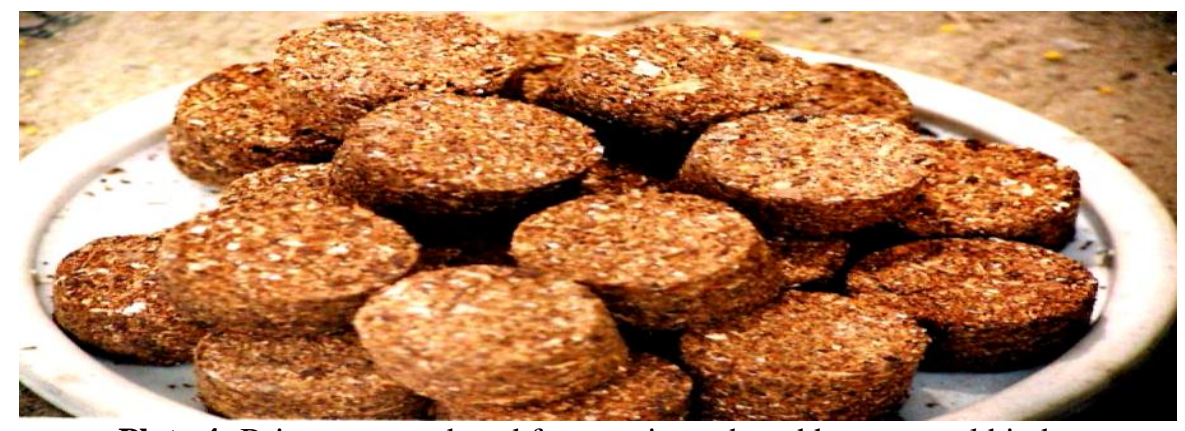

Plate 4: Briquettes produced from maize cob and banana peel binder

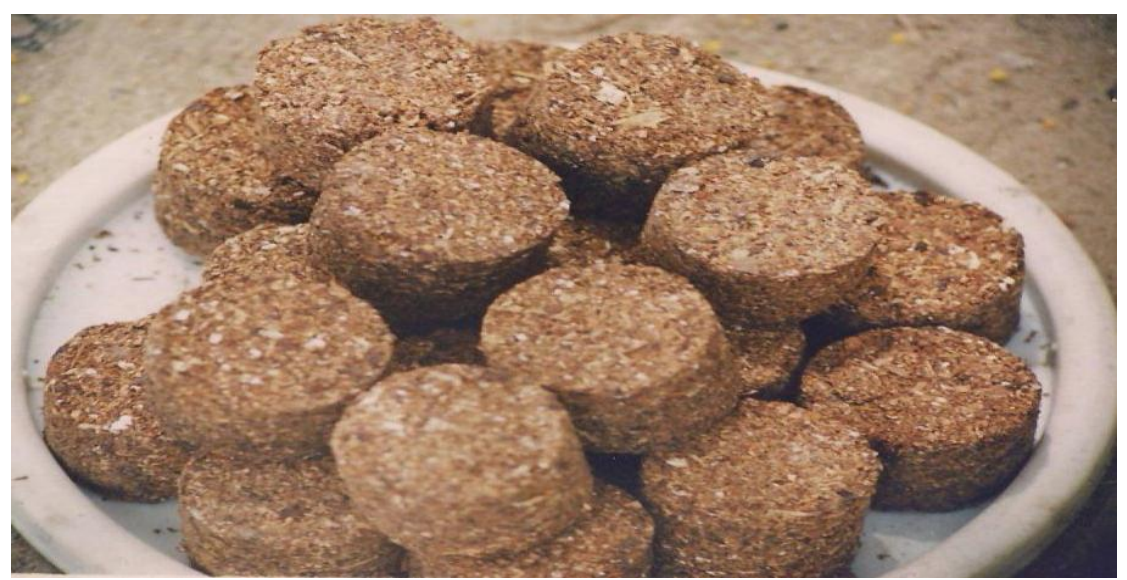

Plate 5: Briquettes produced from sugarcane baggasse and cassava peel gel binder

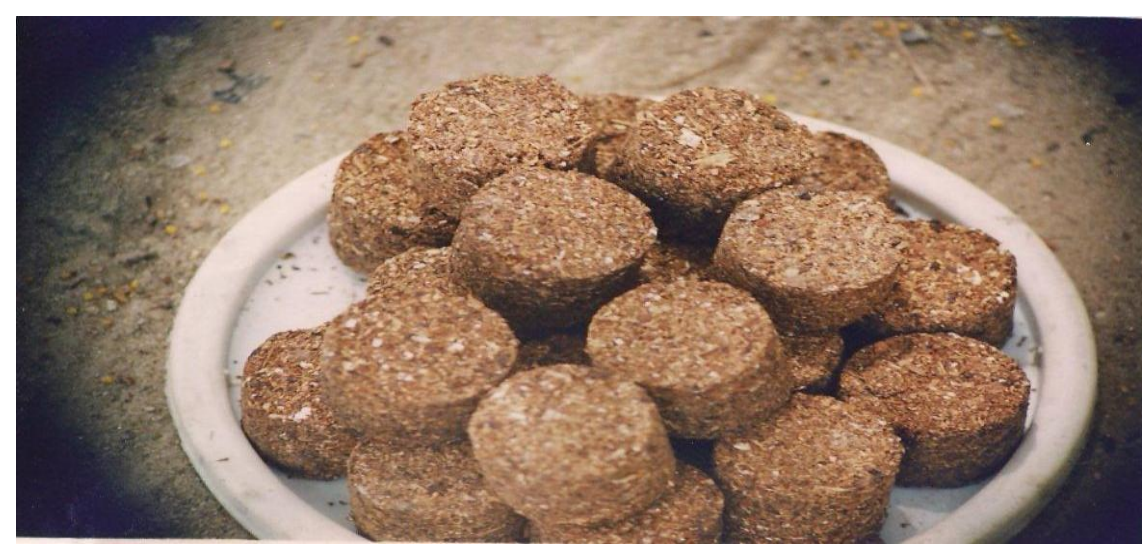

Plate 6: Briquettes produced from sugarcane baggasse and banana peel binder 


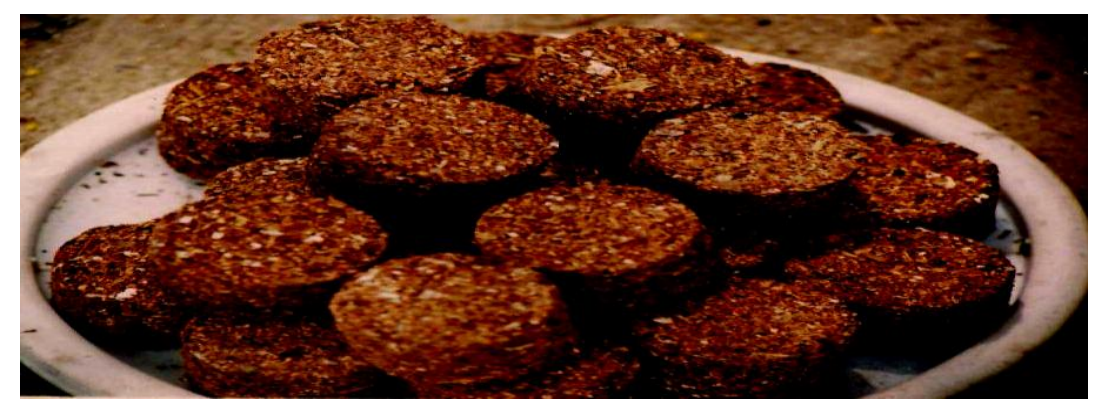

Plate 7: Briquettes produced from groundnut shell and cassava peel gel binder

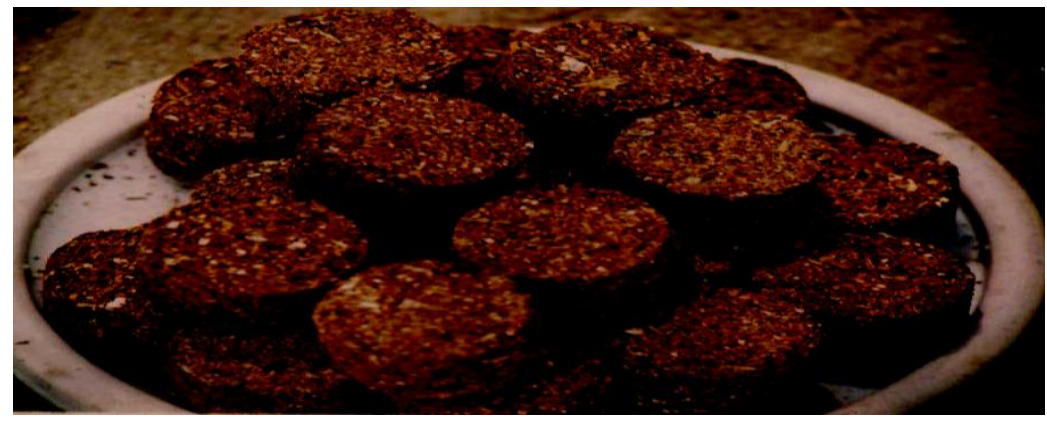

Plate 8: Briquettes produced from groundnut shell and banana peel binder

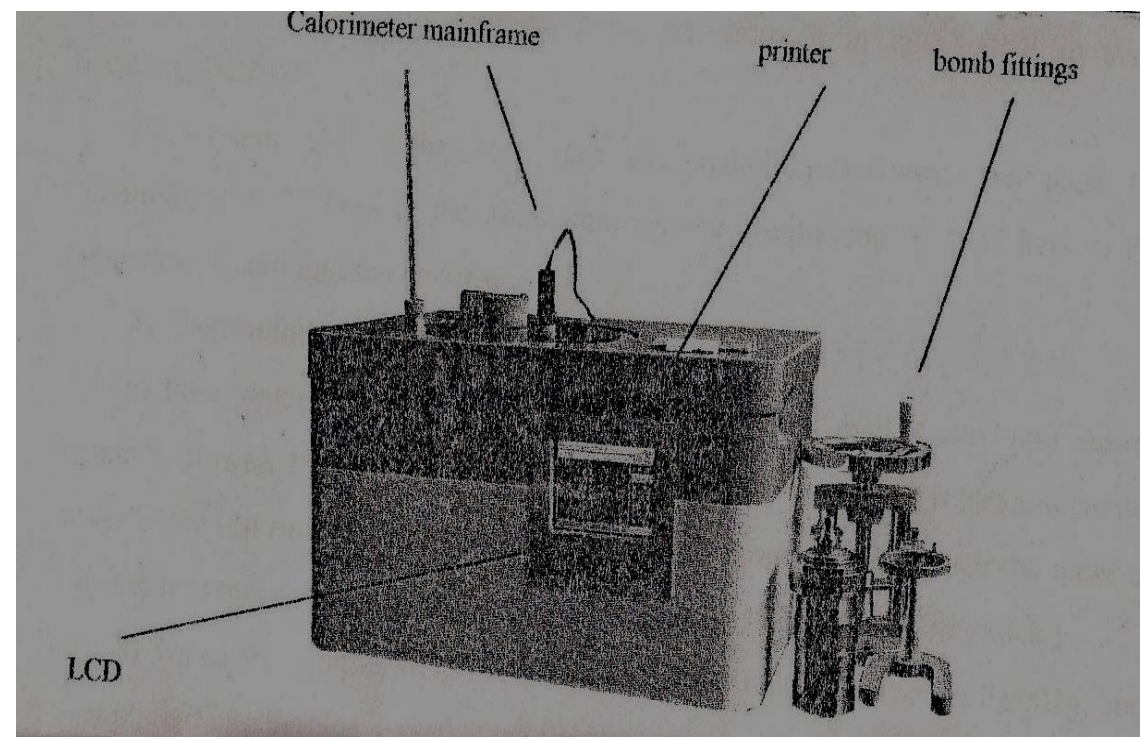

Plate 9: The XRY - B1 Oxygen Bomb Calorimeter 